\title{
Znaczenie designu opakowania w procesie podejmowania decyzji zakupowych przez konsumentów
}

\section{Relevance of Packaging Design for Customers' Decision-Making Process}

Streszczenie: Polski rynek opakowań rozwija się bardzo dynamicznie. Rozwój gospodarki, zmiany stylu życia ludności czy też wzrost świadomości i wymagań konsumentów, zwłaszcza w zakresie podejmowania decyzji zakupowych, wymuszają na przedsiębiorcach ciągly rozwój i poszukiwanie nowych rozwiązań w skutecznej ekspozycji produktów. Wraz ze wzrostem konkurencyjności przedsiębiorstw na rynku rośnie też znaczenie samych opakowań. Obecnie ich funkcją nie jest już tylko ochrona lub informacja o produkcie. Coraz częściej opakowanie traktowane jest jako swoiste narzędzia marketingowe, które wspomaga przywiązanie klienta do marki. Celem pracy jest ukazanie, jak ważna, a zarazem niedoceniana w dzisiejszych czasach, jest rola designu opakowania. W pierwszej kolejności przedstawione zostały rozważania teoretycznie, natomiast w dalszej części zaprezentowano cząstkowe wyniki ankiety, dotyczącej wpływu opakowania na decyzje zakupowe poszczególnych pokoleń konsumentów. Główne pytanie badawcze brzmiało: Czy opakowanie i jego atrybuty odgrywają rolę w procesie zakupowym i w trakcie użytkowania oraz czy są one tożsame w zależności od pokolenia nabywców? Dodatkowo podjęto próbę odpowiedzi na pytania o rolę funkcjonalności opakowania, jego elementów wizualnych, opisu na opakowaniu, jak i o wpływ innowacyjności i zmian w opakowaniu na podejmowane decyzje o zakupie produktu przez konsumentów.

\begin{abstract}
Polish packaging industry is rapidly evolving. Market development, lifestyle changes, and raising customers' awareness, especially in the purchasing decision-making process, demand the continuing business development and searching for new developments for effective product exposure. With the growing competitiveness, the role of packaging design is growing on the market. Currently a product protection and information is not its main function, but communication, that supports a brand loyalty. The idea of the article is to give a picture that packaging design is important and undervalued at the same time. Firstly, theoretical considerations are presented, following by the questionnaire partially results, regarding to the packaging design influence on purchasing decision-making process among different generations. In order to achieve this, basic research question was made: do packaging and its attributes play the role in decision making process as well as during its using? Are they coincided for different generations? Additionally, the author attempted to obtain an objective view of the relevance of functio-
\end{abstract}


nality, visual aspects, description on the packaging, as well as innovativeness and packaging changes for decision making process.

Słowa kluczowe: design; komunikowanie; opakowanie; rozwój nowego produktu, różnorodność pokoleniowa, zarządzanie pokoleniami

Keywords: communication; design; generational diversity; generations management; new product development; packaging

Otrzymano: 10 kwietnia 2019

Received: 10 April 2019

Zaakceptowano: 12 sierpnia 2019

Accepted: 12 August 2019

\section{Sugerowana cytacja/Suggested citation:}

Dziadkiewicz, A. (2019). Znaczenie designu opakowania w procesie podejmowania decyzji zakupowych przez konsumentów. Przedsiębiorczość - Edukacja [Entrepreneurship - Education], 15(2), 125-138. doi: 10.24917/20833296.152.9

\section{Wstęp}

Proces podejmowania decyzji zakupowych przez konsumentów bywa złożony i często skomplikowany. Klienci podlegają głębokim wpływom społecznym, psychologicznym oraz emocjonalnym. Czasem o zakupie decyduje chwila, innym razem zakupy są poprzedzone długim planowaniem.

$\mathrm{W}$ procesie podejmowania decyzji coraz większą rolę przypisuje się opakowaniu. W przeszłości pełniło ono głównie funkcję ochronną oraz informacyjną. Obecnie staje się narzędziem marketingowym, nazywanym nie bez przyczyny niemym sprzedawcą. Powodem tego jest m.in. rosnąca liczba sklepów samoobsługowych, w których rola sprzedawcy, będącego zarazem doradcą, została zredukowana do minimum.

Niniejszy artykuł ma na celu wyjaśnienie roli opakowania w podejmowaniu decyzji zakupowych przez konsumentów w różnym wieku oraz zwrócenie uwagi na ryzyko jego marginalizacji. W tym celu sformułowano główne pytanie badawcze: Czy opakowanie i jego atrybuty odgrywają rolę w procesie zakupowym i w trakcie użytkowania oraz czy są one tożsame w zależności od pokolenia nabywców?

Dodatkowo podjęto próbę odpowiedzi na pytania o rolę funkcjonalności opakowania, jego elementów wizualnych i znajdujących się na nim opisów, a także - innowacyjności i wpływu zmian w opakowaniu na decyzje o zakupie produktu przez konsumentów.

\section{Ewolucja w projektowaniu opakowań}

Współczesny przemysł opakowaniowy ma za sobą długą historię. Na przestrzeni wieków opakowanie zmieniało swoje funkcje i zastosowanie. Odpowiednio zaprojektowane wysyła sygnały, które mają wpływ na sposób, w jaki konsument postrzega zawarty w nim produkt, oddziałuje na jego zachowania i podejmowane przez niego decyzje zakupowe (Lisińska-Kuśnierz, Ucherek, 2004).

Wydarzeniem, które miało niewątpliwy wpływ na rozwój i ewolucję opakowalnictwa, była rewolucja przemysłowa i związane z nią przemiany społeczne, kulturowe i technologiczne. W czasie jej trwania wzrosło zapotrzebowanie na produkty jakościowe, a funkcja 
opakowania zmieniła się radykalnie. Postępująca budowa dróg i kolei wpłynęły na rozwój handlu i tym samym na poprawę dostępności wielu produktów. Towary coraz częściej były transportowane, a to spowodowało, że narodziła się potrzeba odpowiedniego ich opakowania. W dużej mierze jednak opakowania były zarezerwowane dla produktów luksusowych, takich jak biżuteria, buty i żywność. Ceny tych towarów były wysokie, a opakowanie po zużyciu produktu lub jego rozpakowaniu miało dalej służyć użytkownikowi.

Po I wojnie światowej w Europie rynek opakowań zaczął przechodzić transformację. Pojawiły się rozwiązania innowacyjne, które wpłynęły na obniżenie cen opakowań. Wprowadzono m.in. szkło formowane, metalowe puszki, pudła kartonowe i celofan. Wciąż jednak wiele produktów było sprzedawanych luzem, a rolą sprzedawcy było ich zapakowanie i zważenie. W tym czasie pojawiły się pierwsze produkty podrobione, imitujące te oryginalne, ale o znacznie gorszej jakości. Dostrzegając zagrożenie ze strony nieuczciwej konkurencji, producenci zaczęli znakować opakowania. Pierwsza połowa XX w. to także rozwój supermarketów, które wpłynęły drastycznie na zmiany w dystrybucji i konsumpcji.

Po zakończeniu II wojny światowej nastąpił gwałtowny wzrost gospodarczy, połączony ze wzrostem dochodów. Na rynku opakowań pojawiły się aluminium i tworzywa sztuczne. Materiały, które wykorzystywano w przemyśle, były coraz lepsze, bardziej wytrzymałe, lżejsze, elastyczne i co najważniejsze - tańsze. Powoli ograniczano papier i szkło, zastępując je tworzywami sztucznymi i metalowymi.

Koniec XX w. to gwałtowny rozwój technologii cyfrowych, m.in. druku cyfrowego. Funkcją opakowania stało się przede wszystkim wyróżnienie produktów danej firmy. Wzrosła też edukacja w zakresie ekologii, co spowodowało, że o opakowaniach zaczęto dyskutować w kategorii odpadów zagrażających środowisku. Powszechne wykorzystanie plastiku oraz niskie ceny opakowań ugruntowały nabywców w przekonaniu, że opakowanie jest zbędne i po użyciu należy je wyrzucić. Tak zaczęły tworzyć się gigantyczne wysypiska śmieci, które stały się niechlubną wizytówką pokolenia X, nazywanego właśnie z tego powodu "pokoleniem śmieci” (Dziadkiewicz, Nieżurawska, 2017). Aby ukrócić ten proceder, w 2000 r. EPA (Environmental Protection Agency) stworzyła rygorystyczne przepisy dla przedsiębiorstw w celu kontrolowania i ograniczania wpływu opakowań na środowisko. Konsekwencją poszukiwania rozwiązań na rzecz optymalizacji odpadów stało się świadome projektowanie opakowań (Bugusu, Marsh, 2007).

Na ewolucję opakowań w XXI w. wpływają trendy społeczne. Można do nich zaliczyć m.in. zmniejszenie wielkości gospodarstw domowych ${ }^{1}$. Rośnie też popyt na opakowania wielokrotnego użytku typu Ready to Go (RTG), a więc takie, które są gotowe do zabrania ze sobą - butelki na wodę i napoje izotoniczne, wypierające jednorazowe butelki na soki i napoje gazowane. Opakowania mają być lekkie, poręczne i nietłukące się. Szkło jest wypierane przez plastik, zamiast kapsli pojawiają się nakrętki. Pojawiła się nowa objętość (inna dla dzieci, dla sportowców i do kobiecej torebki). Nowością są też opakowania na napoje gorące, tzw. Ready to Drink (RTD). W projektowaniu liczy się funkcjonalność i ergonomia.

Kolejnym trendem jest nacisk na autentyczność i oryginalność, np. unikalne dodatki, egzotyczne wzory, kulturowo naznaczone opakowania, produkty personalizowane, opakowanie jako gadżet. Z drugiej strony, trend na prozdrowotność zakłada wypieranie

${ }^{1}$ Przewiduje się, że w 2020 r. liczba jedno- i dwuosobowych gospodarstw domowych wyniesie niemal 70\%, podczas gdy w 2001 r. wynosiła $52 \%$. 
plastiku przez szkło m.in. z uwagi na migracje związków chemicznych do produktu (np. BPA). Designerzy często podają na opakowaniu kaloryczność żywności, wprowadzają kontrolę porcji i zabezpieczenia przed podróbkami. Projektowane są także opakowania inteligentne (dotyczy to zwłaszcza produktów żywnościowych), które za pomocą interaktywnych wskaźników są czułe na zmiany temperatury, chemiczne reakcje, sygnalizują nieszczelność itp. Podobnie działają opakowania aktywne, których zadaniem jest przedłużanie trwałości i zachowanie produktu w formie niezmienionej. Coraz większy jest nacisk na ekologię i recykling: w ekoopakowaniach dominują minimalizm i naturalne materiały, takie jak len, bawełna, drewno i ceramika.

Zmiany demograficzne, tj. starzenie się społeczeństwa, wymuszają również zmiany $\mathrm{w}$ designie - obecnie projektuje się mniejsze rodzinne opakowania oraz produkty typu antiageing, eksponujące takie cechy, jak witalność, energia, długowieczność. Na końcu należy zauważyć, iż współcześnie również w praktyce marketingowej wiele komunikatów marketingowych opiera się na przedstawieniu istoty innowacyjności produktu, podkreślając tenże innowacyjny charakter przez ekspozycję np. nowego designu, nowych składników czy nowych rozwiązań technicznych (Badowska, 2014).

\section{Rola designu opakowania}

Wpływ wyglądu i funkcjonalności opakowania na podejmowanie decyzji zakupowych konsumentów sprawia, że rola designu jest niezwykle istotna w procesie tworzenia nowego produktu. Design jest pojęciem wielowymiarowym. Może odnosić się zarówno do procesu projektowania, jak i do efektu końcowego. Trudno go zastąpić jednym polskim odpowiednikiem, ponieważ od strony wizualnej należałoby użyć terminu „wzornictwo”, a jeszcze ściślej - „wzornictwo przemysłowe” (ang. industrial design), z drugiej strony tzw. dobry design to projektowanie funkcjonalne i użyteczne. Termin więc nie powinien być dosłownie tłumaczony na język polski, ponieważ zawiera w sobie podłoże socjologiczne (moda na produkty designerskie), ekonomiczne (przydatność i funkcjonalność produktu), czy też technologiczne (rozwój innowacji).

W związku z tym można wyszczególnić trzy kategorie korzyści wynikające z użytkowania opakowania: użytkowe, semiotyczne i hedonistyczne (Bloch, 2011). Pierwsza grupa jest skupiona wokół funkcjonalności opakowania oraz komfortu jego użytkowania. Opakowanie powinno być praktyczne, proste w obsłudze oraz łatwe do zutylizowania. Równie ważna jest jego ergonomia rozumiana jako odpowiednie dopasowanie opakowania do produktu, jak i do potrzeb jego nabywcy.

Semiotyczne elementy designu pozwalają opakowaniu zastąpić sprzedawcę. Opakowanie pełni funkcję komunikacyjną: informuje o zawartości, pochodzeniu, składzie, producencie itp. Na podstawie tych komunikatów nabywca nie tylko zdobywa informacje o produkcie, ale także wyrabia sobie opinię na temat producenta, kreując w świadomości konkretny wizerunek danej marki.

Patrząc pod kątem estetyki, najbardziej istotne dla nabywcy są korzyści hedonistyczne. Od dawna mówi się bowiem, że nabywcy kupują emocje, dlatego produkt ma przede wszystkim sprawiać przyjemność. Pierwszy impuls to obcowanie z opakowaniem, które podobnie jak produkt, ma działać na zmysł wzroku, dotyku, a nawet węchu i słuchu. W parze z elementami niewerbalnymi idą elementy werbalne, tj. marka, nazwa itp. (Butkeviciene, Stavinskiene, Rutelione, 2008). 
Często o wyborze produktu decydują przyzwyczajenia, wspomnienia i pozytywne doświadczenia (Rundh, 2009; Creusen, Veryzer, Schoormans 2010). Równie ważne są: czas, zaangażowanie nabywcy oraz rodzaj podejmowanej decyzji zakupowej. Im mniej czasu, który klient może poświęcić na zapoznanie się z ofertą na półce sklepowej i im dłuższy czas istnienia produktu na rynku, tym klient będzie bardziej opierał się na wyglądzie opakowania. Co więcej, większość klientów szuka produktu właśnie po opakowaniu. Gdy zaś produkt jest nowy na rynku, czynnikiem decydującym o wyborze produktu będą elementy wizualne opakowania.

W przypadku produktów luksusowych oraz dóbr kupowanych rzadko opakowanie odgrywa marginalną rolę. Natomiast biorąc pod uwagę dobra pierwszej potrzeby lub te kupowane impulsywnie, należy zauważyć, że nabywcy kierują się tylko i wyłącznie przednią częścią opakowania, nawet bez brania produktu do ręki (Clement, 2007; Stewart, 1996; Silayoi, Speece, 2004; Kotler, Keller, 2013).

W marketingu design opakowania może być rozumiany jako (Jerzyk, 2014):

- relacja funkcji i formy (wartość usługowa opakowania oraz sposób jej prezentowania) - jest to najbardziej powszechne ujęcie designu opakowania,

- przesłanie centralne i peryferyjne (informacje konieczne i pożądane do przekazania konsumentowi, zaprezentowane w sposób atrakcyjny i skuteczny),

- interakcja struktury i symboliki (poprawna kompozycja opakowania w odniesieniu do zasad komunikacji marketingowej oferuje wartość dodaną w postaci artefaktów) opakowanie dostarcza wrażeń natury sensorycznej i wrażeń aktywizujących emocje.

Marketingowa rola opakowania oraz jego związek z każdym z elementów marketingu-mix są tak duże, że niejednokrotnie mówi się o nim jako o 5P w mieszance marketingowej. W tym aspekcie opakowanie ma za zadanie budować określony wizerunek firmy, przyciągać uwagę konsumentów, stanowić element wyróżniający w porównaniu z produktami konkurencji i być swoistą reklamą produktu (Ampuero, Vila 2006; Gofman, Moskowitz, Mets 2010).

Opakowanie, nawet w przypadku znanych marek, to ważne narzędzie generujące sprzedaż. Jest odpowiedzialne za inicjowanie i kontynuowanie dialogu z nabywcą. W świecie rosnącej sprzedaży internetowej opakowanie niejednokrotnie jest impulsem do zakupu. Jego design musi uwzględniać pozycję marki, kategorię produktu, grupę docelową oraz przedział cenowy.

Oprócz oryginalnej formy równie ważna jest jakość opakowania. Nierzadko klienci rezygnują z ponownego zakupu produktu tylko dlatego, że to właśnie opakowanie nie spełniło ich oczekiwań: wyginało się podczas użytkowania, przestawała działać pompka, kartony miały niestandardowe wymiary, przez co ich transport był uciążliwy itp.

Obecnie duży nacisk stawia się na eliminację niepożądanych właściwości tworzyw, z których wykonane są opakowania - w przypadku szkła projektanci starają się ograniczyć kruchość, w przypadku papieru - rozerwalność i niską barierowość, w przypadku metalu - podatność na korozję, a w przypadku tworzyw sztucznych - brak biodegradowalności. Istotnym aspektem nowoczesnych opakowań jest ich uszlachetnianie. Poprawie ulegają walory estetyczne, a także wytrzymałość na działanie czynników zewnętrznych. Do ciekawostek należy fakt, że w opakowalnictwie zastosowano mikrokapsułki uwalniające określony zapach. 
W badaniu wzięło udział 596 osób z województw: pomorskiego, kujawsko-pomorskiego, mazowieckiego i warmińsko-mazurskiego (byli to przyszli i obecni studenci, wykładowcy, trenerzy oraz osoby pracujące w biznesie i osoby bezrobotne). Warto zauważyć, że w toku badania okazało się, że niezależnie od wykształcenia, aktywności zawodowej oraz miejsca zamieszkania, odpowiedzi są zbieżne, dlatego pomimo początkowego zamierzenia, by dokonać badania wielowymiarowo (por. tabela 1) zdecydowano się uwzględnić tylko jedno kryterium - przynależność do danej grupy pokoleniowej. Dobór próby miał charakter kwotowy. Badanie przeprowadzono w okresie od października do listopada 2017 r., za pomocą ankiety internetowej (CAWI). Badanie miało charakter wstępny, nie było reprezentatywne. Prowadzono je na podstawie wskaźnika struktury. Kolejnym etapem było zastosowanie testów nieparametrycznych.

Tabela 1. Struktura badanej grupy respondentów

\begin{tabular}{|l|c|l|c|l|c|l|c|}
\hline $\begin{array}{c}\text { Pokolenie } \\
\text { (lata } \\
\text { urodzenia) }\end{array}$ & $\%$ & Wykształcenie & $\%$ & $\begin{array}{l}\text { Aktywność } \\
\text { zawodowa }\end{array}$ & $\%$ & $\begin{array}{l}\text { Miejsce } \\
\text { zamieszkania }\end{array}$ & $\%$ \\
\hline $\begin{array}{l}\text { Pokolenie X } \\
(1964-1980)\end{array}$ & 18,30 & wyższe & 58,00 & $\begin{array}{l}\text { osoby } \\
\text { pracujące }\end{array}$ & 44,60 & $\begin{array}{l}\text { miasto pow. } \\
250 \text { tys. } \\
\text { mieszkańców }\end{array}$ & 61,60 \\
\hline $\begin{array}{l}\text { Pokolenie Y } \\
(1981-2000)\end{array}$ & 62,10 & średnie & 26,00 & $\begin{array}{l}\text { studenci } \\
\text { pracujący }\end{array}$ & 17,40 & $\begin{array}{l}\text { miasto } \\
101-250 \text { tys. } \\
\text { mieszkańców }\end{array}$ & 14,40 \\
\hline $\begin{array}{l}\text { Pokolenie Z } \\
\text { (urodzeni po } \\
\text { 2001 r.) }\end{array}$ & 16,60 & zawodowe & 1,00 & $\begin{array}{l}\text { studenci } \\
\text { niepracujący }\end{array}$ & 16,10 & $\begin{array}{l}\text { miasto do } \\
100 \text { tys. } \\
\text { mieszkańców }\end{array}$ & 19,30 \\
\hline $\begin{array}{l}\text { brak } \\
\text { odpowiedzi }\end{array}$ & 3,02 & podstawowe & 1,00 & uczniowie & 19,50 & wieś & 4,70 \\
\hline & $\begin{array}{l}\text { brak } \\
\text { odpowiedzi }\end{array}$ & 15,00 & $\begin{array}{l}\text { osoby } \\
\text { bezrobotne }\end{array}$ & 2,34 & & \\
\hline
\end{tabular}

Źródło: opracowanie własne

Ze względu na cel badania zapytano respondentów, czy opakowanie ułatwia im proces zakupowy. Zdecydowana większość badanych (91\%) odpowiedziała twierdząco. Wśród osób, które zaprzeczyły, niecałe $7 \%$ to przedstawiciele pokolenia X oraz po $1 \%$ - przedstawiciele pokolenia Y i Z. Można zatem wnioskować, iż opakowanie produktu zapada w pamięć konsumentom i ułatwia chociażby znalezienie produktu na półkach sklepowych.

Analizując rycinę 1, można zauważyć, że funkcjonalność opakowania oraz informacje na nim zawarte są najważniejszym motorem zakupu w opinii pokolenia X (odpowiednio $60 \%$ i $47 \%$ odpowiedzi badanych). Odmienne atrybuty docenia pokolenie milenialsów, które za najważniejsze uznało logo i szatę graficzną (odpowiednio 78\% i 48\% odpowiedzi respondentów). Z kolei w opinii pokolenia Z dominujące wydają się być: logo ( $92 \%$ badanych), szata graficzna (89\% odpowiedzi) i opakowanie, będące dziełem znanego projektanta. Warto zwrócić uwagę, że w przypadku pokolenia $\mathrm{X}$ atrybut w postaci projektu znanej osoby był jednym z najniżej ocenionych stymulantów (4\% odpowiedzi). W przypadku pokolenia Y tylko co piąty badany uznał tę cechę za istotną. Z kolei funkcjonalność, 
tak wysoko oceniona przez pokolenie $\mathrm{X}$, została wyróżniona jako istotna przez mniej niż $40 \%$ respondentów $\mathrm{z}$ pokolenia $\mathrm{Y}$ oraz co piątą osobę z pokolenia $\mathrm{Z}$.

$\mathrm{Z}$ analizy badania wynika również, że treść na opakowaniu, która ułatwia zakup niemal połowie respondentów z pokolenia $\mathrm{X}$, nie odgrywa istotnej roli dla pokolenia $\mathrm{Y}(14 \%$ odpowiedzi respondentów) oraz dla pokolenia $Z$ - 8\% odpowiedzi respondentów. Warto także zwrócić uwagę na cechę w postaci oryginalności opakowania, która jest istotna dla niemal $60 \%$ nastolatków, tymczasem jest niezauważana przez pokolenie X (8\% odpowiedzi respondentów). Co ciekawe, okazuje się, że pomimo edukacji w dziedzinie ekologii, mającej niebagatelny wpływ na projektowanie opakowań, ten atrybut nie jest postrzegany jako decydujący przez żadne pokolenie polskich odbiorców: pokolenia Y i Z uważają ekologiczność opakowania za ważną (tę cechę jako istotną zaznaczyło niemal 40\% milenialsów oraz co trzeci reprezentant pokolenia Z), nie jest ona jednak determinantą zakupu, tak istotną jak elementy wizualne, oryginalność oraz projekt znanej osoby.

Jak wynika $\mathrm{z}$ odpowiedzi udzielonych przez respondentów z pokolenia X na pytanie o najbardziej istotne dla nich cechy w trakcie użytkowania produktu (por. rycina 2), są to: wygoda użytkowania ( $92 \%$ odpowiedzi), wytrzymałość (97\% odpowiedzi), szata graficzna ( $83 \%$ odpowiedzi), estetyka wykonania (79\% odpowiedzi) oraz ochrona produktu $(72 \%$ odpowiedzi).

Cechą obojętną dla pokolenia X okazała się innowacyjność opakowania, jego ekologiczność oraz to, czy został zaprojektowany przez znanego designera. Okazuje się również, że informacje znajdujące się na opakowaniu uzyskują status nieważnych już po dokonaniu zakupów (w odróżnieniu od inicjacji zakupu, kiedy ten atrybut był dla nabywców istotny - por. rycina 2). Analogicznie na rycinie 3 wskazano odpowiedzi respondentów z pokolenia Y.

Analizując rycinę 3, można zauważyć, że cechy uznawane przez pokolenie Y za istotne, to estetyka wykonania opakowania (79\% odpowiedzi), szata graficzna (72\% odpowiedzi) oraz wytrzymałość ( $91 \%$ odpowiedzi). Wysokie miejsce zajmuje także innowacyjność (77\% odpowiedzi). 42\% milenialsów uznało zakres informacji na opakowaniu za istotny. Ekologiczność zaś uznana została za obojętną lub mało istotną. Następnie dokonano analizy pokolenia $Z$ (por. rycina 4$)$.

Na rycinie 4 można zauważyć, że do atrybutów opakowania uznanych za istotne podczas użytkowania produktu wśród reprezentantów pokolenia $Z$ należą: jego innowacyjność ( $81 \%$ odpowiedzi), estetyka wykonania ( $92 \%$ odpowiedzi), szata graficzna ( $82 \%$ odpowiedzi) oraz rodzaj materiału (78\% odpowiedzi). Za niewątpliwie istotną cechę opakowania uznano zaprojektowanie go przez znanego designera (98\% odpowiedzi). Do cech uznanych za nieważne należą informacje na opakowaniu (42\%), zaś funkcja ochronna produktu oraz ekologiczność (odpowiednio 34\% i 31\% odpowiedzi) były cechami obojętnymi.

Na pytanie o ocenę jakości produktu przez opakowanie 77\% respondentów odpowiedziało twierdząco (z czego aż 78\% to reprezentanci pokolenia X). 11\% respondentów uważa, że nie ma korelacji pomiędzy postrzeganiem produktu a opakowaniem (najwięcej odpowiedzi tego typu zaznaczyli przedstawiciele pokolenia $Z-82 \%) .12 \%$ respondentów nie miało zdania na ten temat (65\% odpowiedzi zostało wskazanych przez reprezentantów pokolenia Y). Takie rozłożenie wyników świadczy o tym, że o postrzeganiu jakości produktu, zwłaszcza w opinii respondentów z pokolenia X, decyduje właśnie jego opakowanie. Dodatkowo zapytano o związek pomiędzy opakowaniem produktu a uczuciem 
Rycina 1. Atrybuty opakowania stymulujące proces zakupu

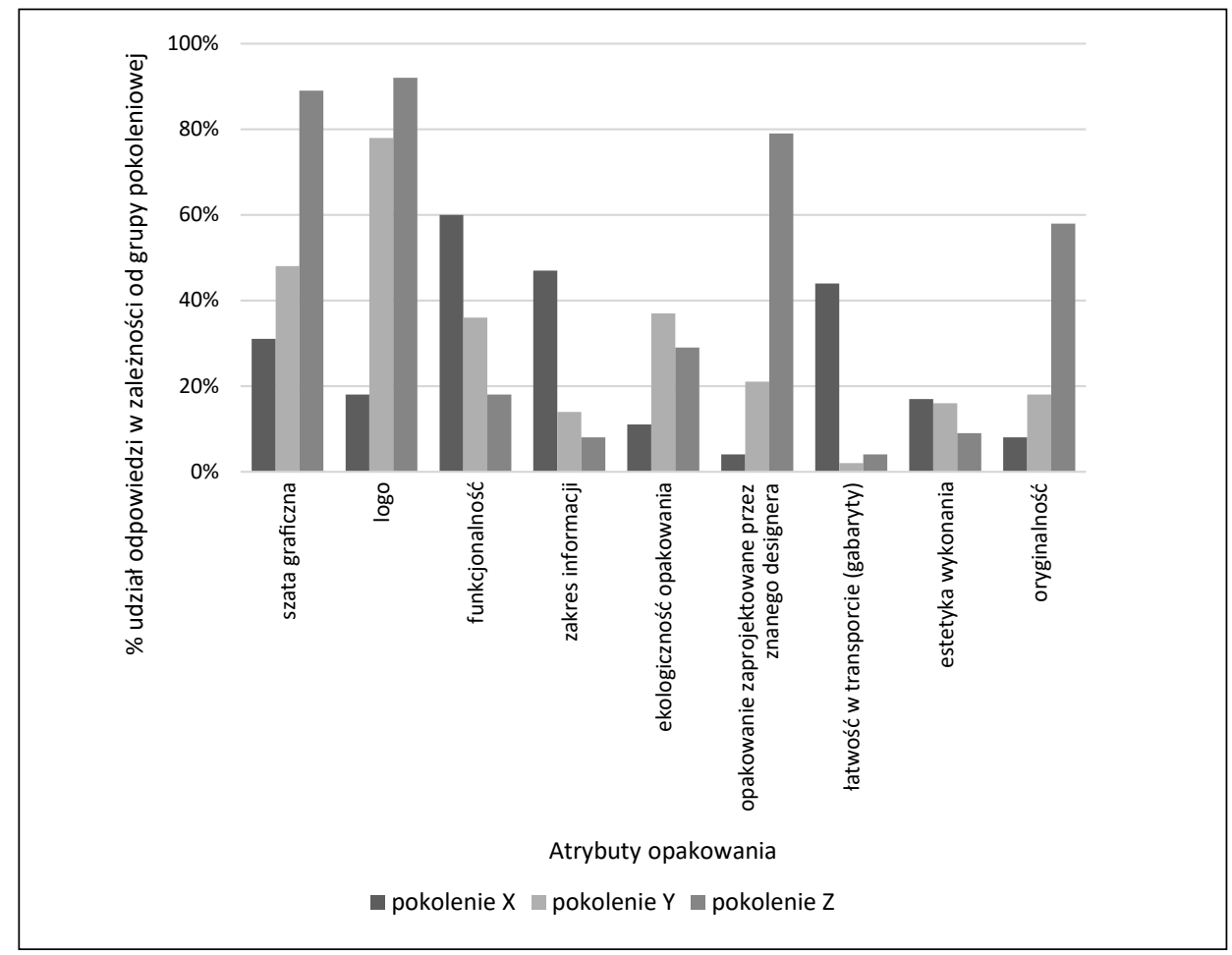

Źródło: opracowanie własne na podstawie przeprowadzonego badania

Rycina 2. Znaczenie poszczególnych cech opakowania dla pokolenia X

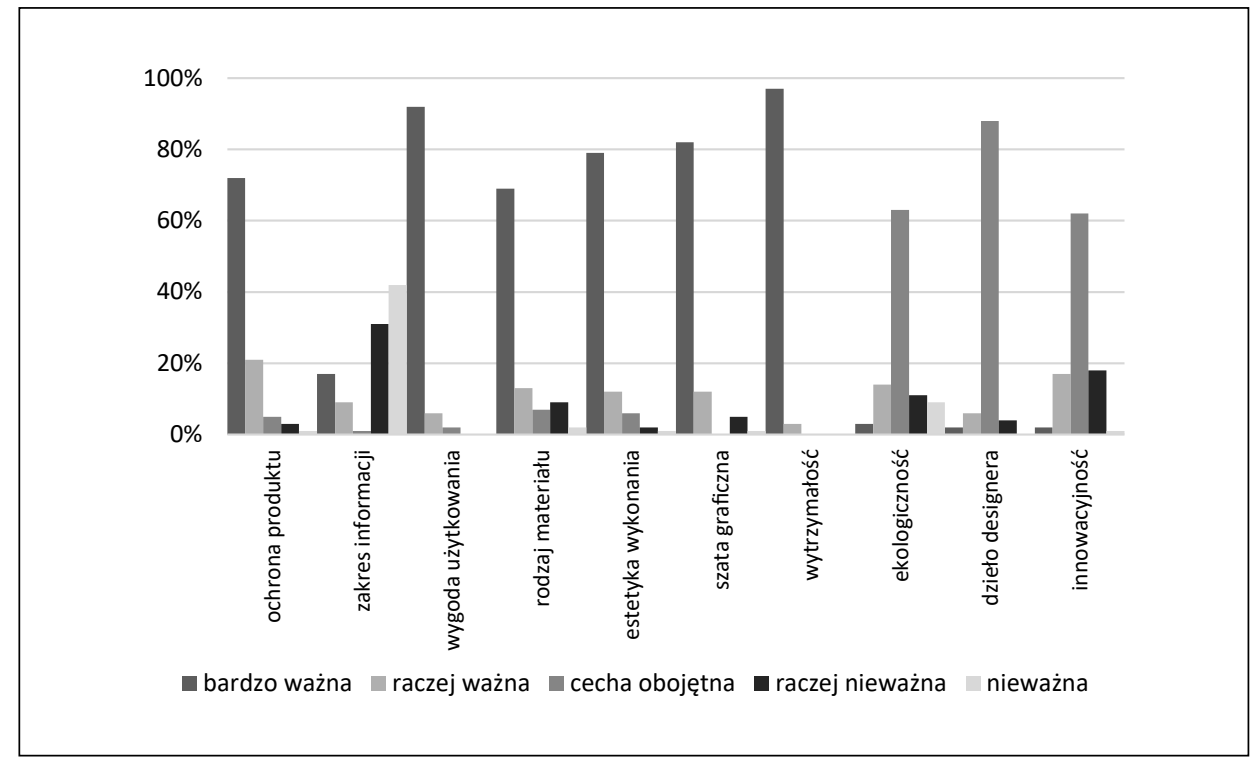

Źródło: opracowanie własne na podstawie badania ankietowanego 
Rycina 3. Znaczenie poszczególnych cech opakowania dla pokolenia $Y$

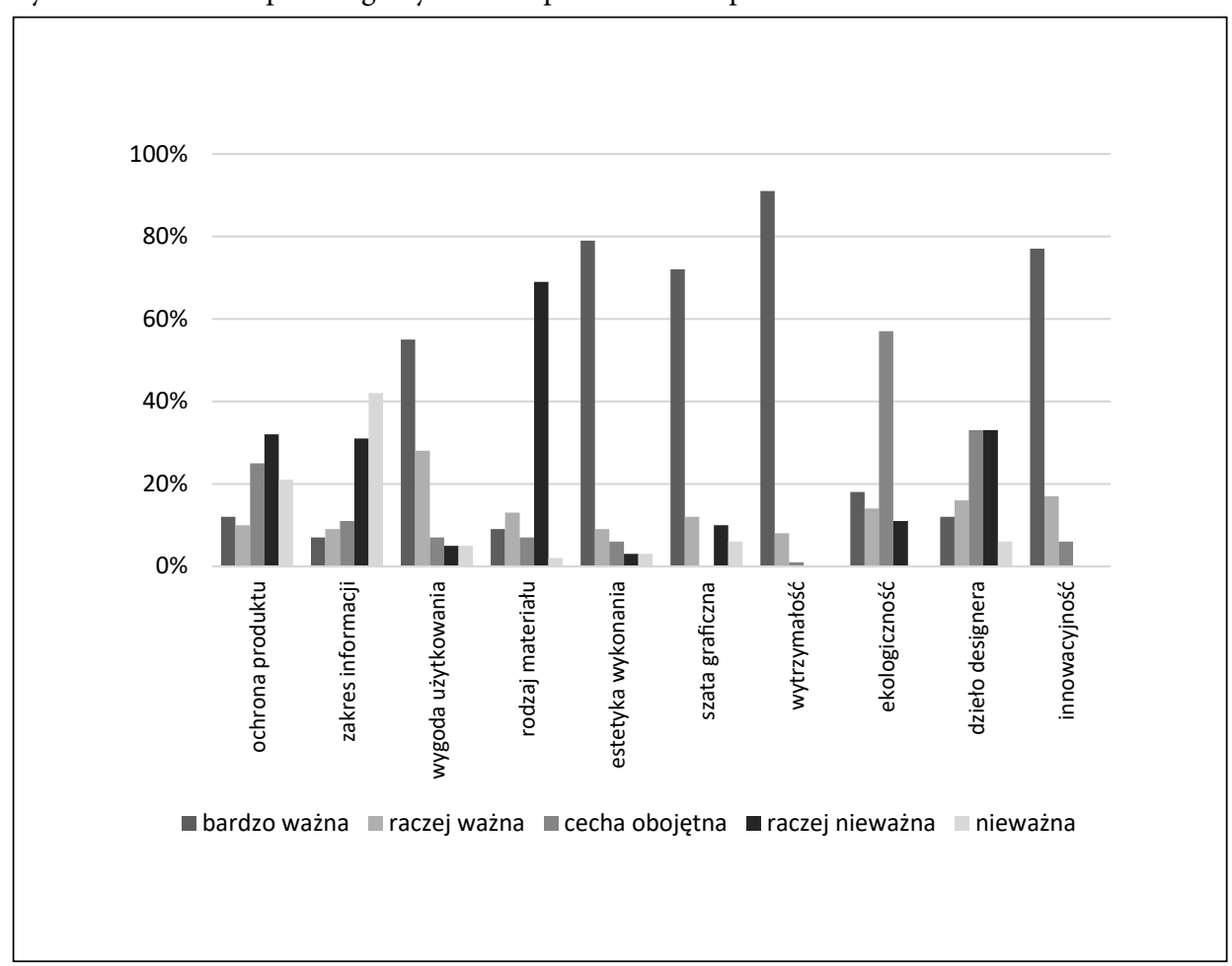

Źródło: opracowanie własne na podstawie badania ankietowanego

Rycina 4. Znaczenie poszczególnych cech opakowania dla opinii ankietowanych z pokolenia Z

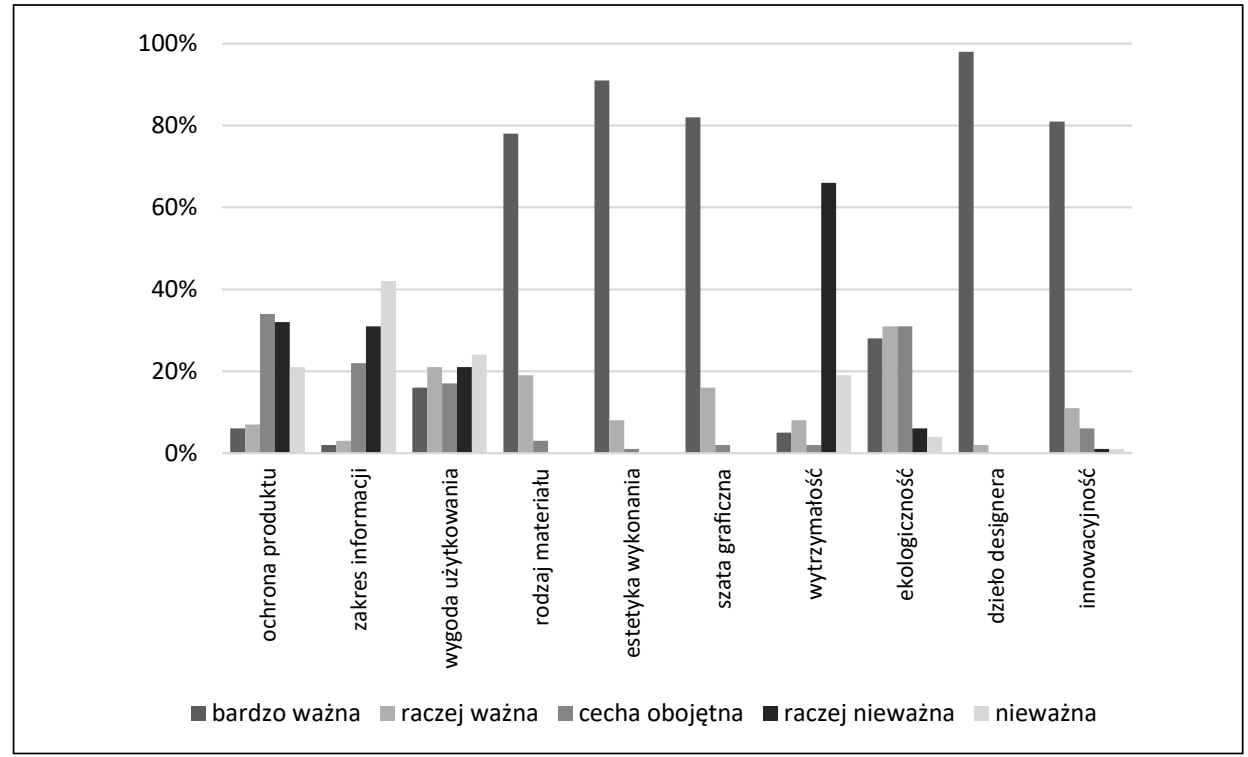

Źródło: opracowanie własne na podstawie badania ankietowanego 
przynależności do określonej grupy społecznej. Zdecydowana większość badanych (67\% respondentów) zgadza się z tym stwierdzeniem (w grupie tej znalazło się 99\% reprezentantów pokolenia $\mathrm{Z}, 65 \%$ milenialsów oraz $12 \%$ osób z pokolenia $\mathrm{X}$ ).

Ponad $80 \%$ ankietowanych przyznało się do zakupu produktu głównie przez pryzmat opakowania (niemal $40 \%$ tej grupy to reprezentanci pokolenia $\mathrm{Y}$, a niemal $60 \%$ to reprezentanci pokolenia Z). Przecząco odpowiedziało 19,4\%, wśród których $76 \%$ badanych to osoby z najstarszej grupy wiekowej (urodzone w latach 1964-1980), 14\% badanych to osoby urodzone między rokiem 1981 a 2000, a 10\% badanych to osoby urodzone po $2001 \mathrm{r}$.

Dodatkowo osoby, które opowiedziały się za zakupem ze względu na interesujące opakowanie, zapytano, czy są skłonne zapłacić za interesujące „designerskie” opakowanie więcej. 37\% respondentów odpowiedziało, że raczej tak, a 18\%, że zdecydowanie tak. Wyniki te wskazują na coraz większe zainteresowanie konsumentów nie tylko funkcjonalnością opakowania, ale też jego wyglądem. Pytając respondentów o ich reakcję na zmianę opakowania znanego im już produktu, odpowiedzi były następujące: irytacja (99\% badanych osób z pokolenia $\mathrm{X}$ i $81 \% \mathrm{z}$ pokolenia $\mathrm{Y}$ ) i utrata zaufania ( $76 \% \mathrm{z}$ pokolenia $\mathrm{X}$ oraz $63 \%$ z pokolenia $\mathrm{Y}$ ). Co ciekawe, te dwie cechy nie były znacząco istotne dla przedstawicieli pokolenia X (kolejno: 15\% i 14\%). Ta najmłodsza grupa badanych wykazuje reakcje odwrotne, związane ze zmianą opakowania - zainteresowanie i entuzjazm (odpowiednio 83\% i 78\% odpowiedzi). Poszczególne odpowiedzi zostały zaprezentowane na rycinie 5.

Można zatem stwierdzić, że zmiana opakowania produktu skierowanego do osób powyżej 20 roku życia powinna być przeprowadzona w sposób dobrze przemyślany i spójny ze strategią marki. Nieumiejętne wprowadzenie nowego opakowania produktu dobrze znanego tej grupie konsumentów może spowodować odwrócenie się od marki i wybranie produktu konkurencji. Tymczasem okazuje się, że zmiana opakowania produktu skierowanego do nastolatków może być skutecznym zabiegiem marketingowym - wzbudza bowiem ciekawość i jest przychylnie odbierana.

Rycina 5. Odczucia respondentów podczas zmiany opakowania

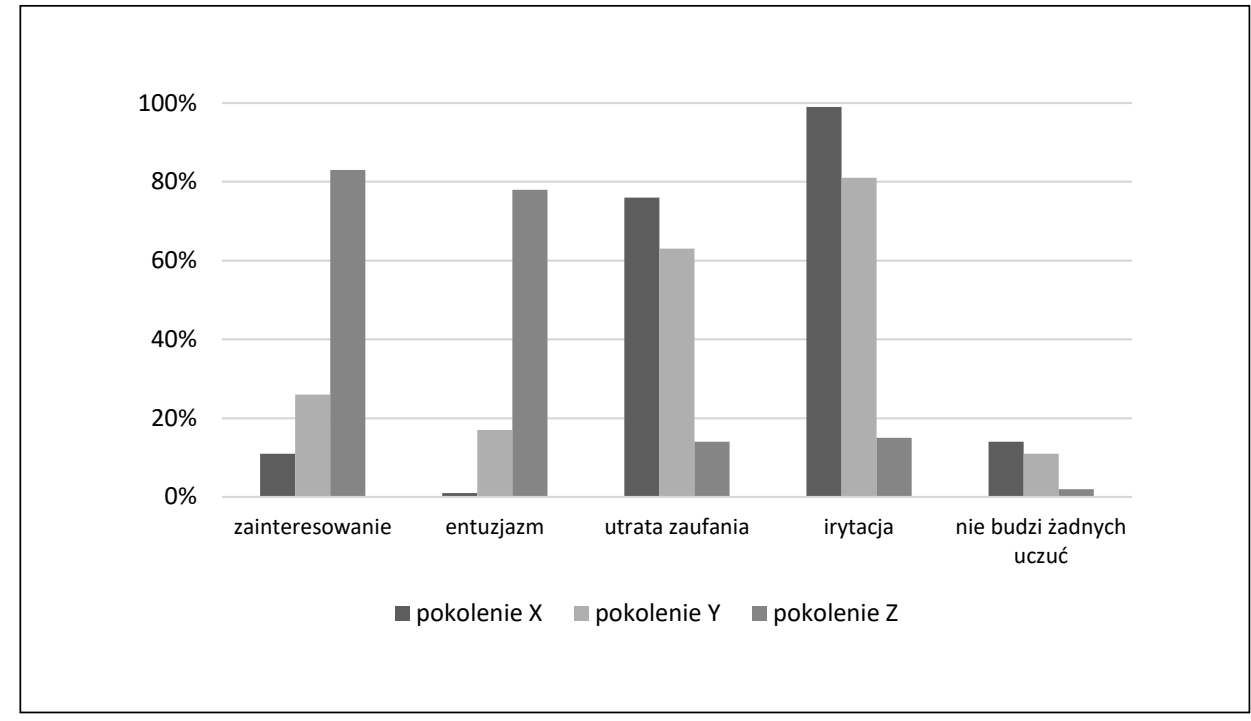

Źródło: opracowanie własne na podstawie badania ankietowanego 
Wnioski

Z przeprowadzonego badania wynika, że konsumenci z pokolenia X najczęściej w swoich wyborach kierują się przyzwyczajeniem i wysoką jakością produktów. Mają zaufanie do tych marek, których pozycja jest już ugruntowana na rynku. Dodatkowym czynnikiem mającym wpływ na wybór produktu jest cena, która zawsze powinna być adekwatna do jakości produktu. Osoby z pokolenia X są podatne na działania promocyjne. Cechuje je duża lojalność do produktów, które spełniły ich oczekiwania. Nie potrzebują ciągłych zmian i testowania nowości pojawiających się na rynku. Równie ważne jak produkt jest dla nich opakowanie, które powinno być odzwierciedleniem marki, tzn. nieść spójny z produktem komunikat. Należy jednak mieć na uwadze to, że decyzje zakupowe pokolenia X są często podyktowane sugestiami młodszego pokolenia - Y, mającego większe rozeznanie $\mathrm{w}$ trendach rynkowych i korzystającego $\mathrm{w}$ sposób nieograniczony $\mathrm{z}$ wiedzy zdobytej w internecie. Tworząc więc projekty opakowań dla przedstawicieli pokolenia X, należy mieć na uwadze symbiozę dwóch pokoleń.

Priorytetem wśród reprezentantów pokolenia Y będzie nie tradycja, lecz unikatowość marki. Coraz częściej reprezentanci tego pokolenia decydują się na zakup produktów przedsiębiorstw nowo powstałych, krótko istniejących na rynku, niemających wyrobionej marki. To, co dla nich jest najważniejsze, to oryginalność, częste wprowadzanie nowości i kreowanie serii limitowanych. Cena, w odróżnieniu do motywów postępowania pokolenia X, nie jest wyznacznikiem zakupu. Osoby z pokolenia Y nie koncentrują się na jednym poziomie ekspozycji produktów w sklepach, lecz wybierają produkty $z$ różnych półek sklepowych. Projektując opakowania, designerzy powinni zwrócić uwagę na rozwiązania proekologiczne. Warto podkreślić, że opakowanie z naturalnych materiałów, może być nawet motywatorem do kupna produktów w znacznie wyższej cenie. $Z$ punktu widzenia celu artykułu warto podkreślić, że jest to pierwsze pokolenie, które idąc za trendami XXI w., woli kupować produkty bez opakowania. Aczkolwiek, kiedy już to opakowanie występuje, powinno być ono funkcjonalne, wygodne w obsłudze i ciekawie zaprojektowane (na te cechy nie zwracają uwagi dzisiejsi trzydziesto- i czterdziestolatkowie). Milenialsi cenią sobie świeże pomysły i element zaskoczenia. Są bardziej podatni na bodźce, które niesie ze sobą starannie zaprojektowane opakowanie - ciekawą historię (tzw. story telling), wywołanie emocji, a także kontakt, który firma próbuje nawiązać za pośrednictwem produktu.

Generacja Z (obecni nastolatkowie), mająca do czynienia z technologią od najmłodszych lat, bardziej niż pozostałe pokolenia jest skupiona na treściach online. Według A. Dziadkiewicz (2017), pokolenie to chce angażować się w tworzenie produktu oraz decydować o ostatecznym jego kształcie. Najczęściej przedsiębiorcy docierają do tych klientów za pomocą mediów społecznościowych, aplikacji mobilnych oraz tzw. influencerów, czyli liderów opinii. Co ciekawe, jest to pierwsze pokolenie, które będąc usatysfakcjonowane $\mathrm{z}$ zakupu albo dumne $\mathrm{z}$ nabycia danych produktów, prezentuje je w internecie, stając się jakoby ich żywą reklamą. Osoby z pokolenia Z lubią identyfikować się z produktem, którego nabycie wyznacza przynależność do danej grupy społecznej (społeczność Apple, społeczność Starbucks itp.). Opakowanie powinno być więc spójne z produktem zawartym w jego wnętrzu. 
Podsumowanie

Dzięki przeprowadzeniu ankiety dotyczącej wpływu opakowania i jego designu na podejmowanie decyzji zakupowych można skonstatować, iż opakowanie, chociaż wciąż nie zawsze doceniane przez użytkowników, ma ogromny wpływ na wybór produktu. Zdecydowana większość dzisiejszych konsumentów (niezależnie od wieku) kieruje się właśnie opakowaniem produktu już na etapie podejmowania decyzji zakupowych.

Kolejnym aspektem są cechy i elementy opakowania. Z przeprowadzonych badań wynika, że konsumenci pokolenia X świadomie stawiają przede wszystkim na funkcjonalność danego opakowania, informacje na nim zawarte oraz aspekty logistyczne. Niemniej jednak odpowiedzi udzielone na pytanie o istotność poszczególnych składowych opakowania na etapie podejmowania decyzji zakupowych wyraźnie sugerują, że coraz częściej kupujący, zwłaszcza reprezentujący pokolenia Y i Z, zwracają uwagę na wygląd opakowania danego produktu oraz na jego twórcę. Wyniki wskazują, iż kształt, wielkość, logo, kolor opakowania, a nawet zlecony projekt zaczynają być równie istotne, a często najważniejsze podczas robienia zakupów.

Badania wskazują też, że coraz bardziej popularne są kwestie dotyczące ekologiczności opakowania, jednak wciąż nie stanowią one elementu kluczowego, tak podczas zakupów, jak i później, podczas korzystania z produktu. Wyniki badania wskazują, że najbardziej aktywną grupą w tym zakresie jest pokolenie Y, które wykazuje się największą świadomością podejmowanych decyzji zakupowych. Jednakże można zauważyć, że pozostałe grupy badanych nie pozostają bierne. Słusznym wydaje się zatem stwierdzenie, iż ekologia to trend, który jest w fazie rozwoju.

Następnie warto podkreślić sposób, w jaki konsumenci postrzegają opakowanie produktu. Większość z nich uważa, iż opakowanie odzwierciedla jakość zawartego w nim produktu, a także może wywoływać poczucie przynależności do pewnej grupy społecznej. Jest to szczególnie istotne z punktu widzenia komunikacji związanej z opakowaniem. Dodatkowo, ponad połowa ankietowanych przyznała, że nieraz kupiła produkt przez pryzmat jego opakowania, a co więcej - byłaby skłonna przeznaczyć większą kwotę na dany produkt tylko ze względu na jego atrakcyjne opakowanie. $\mathrm{Z}$ analizy zebranego materiału można także wywnioskować, iż konsumenci w pewien sposób przywiązują się do opakowania znanego im wcześniej produktu i chociaż w większości są zainteresowani jego zmianą, to nierzadko budzi ona $u$ nich poirytowanie.

Podsumowując dokonaną analizę, można stwierdzić, że podstawowymi funkcjami opakowania, na które konsumenci zwracają uwagę w czasie podejmowania decyzji zakupowych, są funkcje: ochronna i informacyjna. Niemniej jednak jego design staje się niezwykle istotnym atrybutem $\mathrm{w}$ procesie podejmowania decyzji o zakupie, a jego popularność rośnie wraz z tworzeniem się nowych pokoleń nabywców. Z całą pewnością można stwierdzić, iż występują wyraźne różnice w postrzeganiu opakowania przez konsumentów będących przedstawicielami danych grup pokoleniowych. Dla najstarszych liczą się marka oraz informacje producenta, milenialsi skupiają się na innowacyjności opakowania, jego estetyce i ekologiczności. Natomiast osoby z generacji Z patrzą na opakowanie pod kątem jego oryginalności, znanego twórcy i możliwości przynależenia do określonej grupy społecznej.

W artykule uwidoczniono nie tylko potrzebę dostosowania opakowania do różnych potrzeb grup konsumentów, ale także wskazano złożoność oraz wieloaspektowość tego zagadnienia. 
Literatura

References

Ampuero, O., Vila, N. (2006). Consumer perceptions of product packaging. Journal of Consumer Marketing, 23(2), 100-112. doi: 10.1108/07363760610655032

Badowska, S. (2014). Komunikacja marketingowa innowacji produktowych. Marketing i Rynek, 4, 23-30.

Bloch, P.H. (2011). Product Design and Marketing: Reflections After Fifteen Years. Journal of Product Innovation Management, 28(3), 378-380

Bugusu, B., Marsh, K. (2007). Food Packaging-Roles, Materials and Environmental Issues. Journal of Food Science, 72(3), 48. doi: 10.1111/j.1750-3841.2007.00301.x

Butkeviciene, V., Stavinskiene, J., Rutelione, A. (2008). Impact of Consumer Package Communication on Consumer Decision Making Process. Engineering Economics, 1, 57-65.

Clement, J. (2007). Visual influence on in-store buying decisions: an eye-track experiment on visual influence of packaging design. Journal of Marketing Management, 23(9-10), 917-928. doi: 10.1362/026725707X250395

Creusen, M.E.H., Veryzer, R.W., Schoormans, J.P.L. (2010). Product value importance and consumer preference for visual complexity and symmetry. European Journal of Marketing, 44(9/10),1437145, doi: 10.1108/03090561011062916

Dziadkiewicz, A. (2017). Personalizacja a kastomizacja w marketingu. Zarzadzanie i Finanse, 15(1), 95-108.

Dziadkiewicz, A., Nieżurawska, J. (2017). Świadomość ekonomii cyrkularnej Pokolenia Y jako czynnik przyspieszonego rozwoju gospodarczego regionu. Marketing i Rynek, 10, 405-407.

Gofman, A., Moskowitz, H.R., Mets, T. (2010). Accelerating structured consumer-driven package design. Journal of Consumer Marketing, 27(2), 157-168. doi: 10.1108/07363761011027259

Jerzyk, E. (2014). Design opakowania i jego elementy w procesie podejmowania decyzji zakupowych. Marketing i Rynek, 4, 391-398.

Kotler, P., Keller, K.L. (2013). Marketing. Poznań: Dom Wydawniczy „Rebis”.

Lisińska-Kuśnierz, M., Ucherek, M. (2004). Podstawy opakowalnictwa towarów, Kraków: Wydawnictwo Akademii Ekonomicznej w Krakowie.

Rundh, B. (2009). Packaging design: creating competitive advantage with product packaging. British Food Journal. Emerald Article, 111(9), 988-1002. doi: 10.1108/00070700910992880

Silayoi, P., Speece, M. (2004). Importance of packaging attributes: a conjoint analysis approach. European Journal of Marketing, 41 (11/12), 1495-1517. doi: 10.1108/03090560710821279

Stewart, B. (1996). Packaging as an effective marketing tool. Boca Raton. Florida: CRC Press.

Anna Dziadkiewicz, dr nauk ekonomicznych w zakresie nauk o zarządzaniu, Uniwersytet Gdański, Wydział Zarządzania, Katedra Marketingu. Ukończyła Uniwersytet Mikołaja Kopernika w Toruniu oraz London School of Economics, a także studia podyplomowe: Menedżer Projektu Badawczo-Rozwojowego, Akademia Trenera Biznesu oraz dwuletnie Europejskie Studia Specjalne w Centrum Jeana Monneta przy Wydziale Prawa na UMK w Toruniu. Obecnie jest wykładowcą w Katedrze Marketingu na Uniwersytecie Gdańskim. Jest także właścicielem firmy szkoleniowej AD-futuro. $\mathrm{W}$ ostatnich latach prowadziła szkolenia $\mathrm{w}$ zakresie design management, public relations, marketingu i budowania wizerunku marki. Koordynowała projekty międzynarodowe, a obecnie pełni funkcję głównego kierownika informacji w jednym $\mathrm{z}$ nich. Jej zainteresowania dotyczą podejścia design management i projektowania usług opartego na podejściu design thinking.

Anna Dziadkiewicz, $\mathrm{PhD}$ in Economics in the field of management. She has graduated from the Nicolaus Copernicus University in Torun, Poland and London School of Public Relations; completed post-graduate studies in the field of Managing Scientific-Research Project, as well as Business Coach Academy and a two-year European studies at Jean Monnet Centre. She is a lecturer of the Marketing Department at the University of Gdansk. She is an owner of a training and consulting company $\mathrm{AD}$-futuro. For the past few years she has been conducting training courses on design 
management, public relations, marketing, enterprise brand building. She has coordinated a number of international projects and currently she is a Head Information Manager in one of them. Her interests revolve around design management and service design according to design thinking approach.

ORCID: 0000-0003-1880-4077

Adres/Address:

Uniwersytet Gdański

Wydział Zarządzania

ul. Armii Krajowej 101

81-824 Sopot, Polska

e-mail: anna.dziadkiewicz@ug.edu.pl 